\title{
Cartels in Hungary: Summary of a Bolyai Research Project
}

Being awarded the János Bolyai Research Scholarship (BO/00198/18/9) in 2019 permitted the continuation of my research into cartel law. The chosen research topic was "The Regulation and Practice of Cartel Law in the $20^{\text {th }}$ Century, with an International Outlook". The dissemination of the findings of the Bolyai research project and the promotion of the study was supported by funding from the Ministry of Innovation and Technology's New National Excellence Program, codename ÚNKP-20-5, funded by the National Research, Development and Innovation Fund.

During the conduct of the research, I focused on the historical examination of cartel law in the first half of the $20^{\text {th }}$ century, especially the codification and practice of the $20^{\text {th }}$ Act of 1931. The economic and social changes following World War had an effect on legal development as well, and because of this, state intervention and participation also became more and more prevalent in private law, in order to keep fair trade and the interests of consumers in mind. This was especially valid due to the involvement of cartels, and it basically manifested itself in the creation and regulation of cartel supervisory agencies. This three-year long research project gave me ample time to collect and analyse primary and secondary sources. Having regard to the Szeged School of Legal History, this was the primary aim during my research. Being awarded the Bolyai Scholarship meant that not only the research could continue, but also the synthesizing of results from prior research, and the processing of the rare missing components, not to mention the further elaboration of archival sources.

The validation of the subsequent results took place during the first year of the research. The economic and social shifts of the first half of the $20^{\text {th }}$ century had an effect on both the regulation of private law relations, and on the introduction of state intervention in order to protect consumer interests. This is why it is necessary to mention the following regulation in connection to the examination of the history of cartel law codification.

Legal control over the prices of public needs and the assurance of fair price policies appeared in the regulation of sharking misuses (i.e. $15^{\text {th }}$ Act of 1920), which can be viewed as the earliest national antecedent of cartel law. In my study Examples of Sharking Misuses in the Practice of the Court of Justice of Szeged, I elaborated upon 
the practices of the usury court of Szeged's Royal Court of Justice (Hungarian National Archives, Csongrád-Csanád County Archives, the papers of the Royal Court of Justice of Szeged, 1942/VII. 1. B.III.).

In the study The Effect of World War I on the Codification of Cartel Law, I examined the history of the codification of cartel law, especially by analysing the papers of the presidential council and the minutes of the parliament. One of the most prevalent social conversations before the legislation was the series of lectures of the Legal Economic Institution of the Hungarian Association of Lawyers in May 1929, where, among others, Ödön Kuncz expressed his opinion on the topic. The political economic background and the regulation of state intervention in this matter also arose during the parliamentary debate of the law. The ministerial justification of the law provides a comprehensive picture of the national and international preludes, and the history of regulation of cartels. One should not forget the courts' legal development efforts, for in this case, these efforts were especially important before the codification of the law. Due to the lack of legislative regulation, only the general principles of private law, more specifically commercial law, provided some support to the formation of judicial decisions.

I examined the operation of one of the most important supervisory organisations, the Cartel Court, through leading cases. The development of cartel law benefited greatly from the legal unification actions of the court. I summarised the theoretical and practical backgrounds of the regulations of lawsuits of public interests in my study The Lawsuit of Public Interest in Cartel Law. The principal mandates of the law regulating cartels also regulated state intervention in private law affairs. In my study Regulation and Practice of Hungarian Cartel law in the $20^{\text {th }}$ Century, I analysed the most important formal legal rules of cartel law, especially the practices of the cartel supervisory agency, by analysing archival sources (for example, Hungarian National Archives, FM papers k-187, Hungarian National Archives Bács-Kiskun County Archives, registry court papers at the Budapest City Archives). The $20^{\text {th }}$ Act of 1931 introduced the rules for lawsuits in the public interest, and its theoretical background and legal practices were elaborated upon in the study entitled The Lawsuit of Public Interest in Cartel Law: Case Law of the Cartel Court in Hungary.

During the second year of the scholarship I published a paper in the Legal History Survey entitled The Initiation of Legal Proceedings in Cartel Cases After the $20^{\text {th }}$ Act of 1931 Came into Effect, where I presented the procedures for initiation of legal proceedings, with great focus on the role of the Legal Director of the Hungarian Treasury. The continued research of the topic meant the description of the procedures of orderly courts (The Procedures of Orderly Courts in Cartel Cases Between the World Wars) by using the remaining submissions which contain verdicts of courts of the first and second instance. In my opinion, in order to examine financial regulations, and not to mention those of procedural law, the information contained in the dispositional and justification sections will help tremendously. Within the framework of the aforementioned study, I summarized my research results according to the cartel cases that reached various courts, including the High Court of Justice. Thanks to discussing specific cases, one shall gain insight into everyday lives of companies after cartel law came into effect. In the pages of my study entitled The Antecedents of the Regulation of the Economic Competition Agreement in the First Part of the $20^{\text {th }}$ Century in Hungary, I described the preambles to the codi- 
fication of Hungarian cartel law in English. During my research, I paid special attention to the European roots of the regulation of Hungarian cartel law, for example, with a description of Austrian and German cartel law (The European Roots of Hungarian Regulation of the Cartels - Special Attention to the Foundation of Cartel Supervisory Public Authorities), in connection to the national institutional history of cartel supervisory agencies. During the examination of cartel supervisory agencies, I also analysed the stipulations of courts of arbitration on cartel agreements and the nullification of their verdicts, and I subsequently described my views on this subject in greater detail in my study Provisions on Arbitration Proceedings Set Down in Cartel Agreements Based on the First Hungarian Cartel Act.

I presented my research results at national and international conferences, and also in short articles on my research: The Beginning of a Bolyai research project: The Historical Examination of Cartel Law; Scholarly Examination of and Report on the Hungarian Cartel Law in the Framework of a Bolyai Scholarship. During the international conference: $16^{\text {th }}$ Annual International Conference on Law (Athens, 15 and 16 July 2019), I organised and conducted a session on legal history entitled "State and Law in the Interwar Period" on topics connected to the research. I also collaborated with David A. Frenkel, Professor Emeritus of the Ben-Gurion University of the Negev in the editorial process of the essay collection "New Studies in History and Law", which contains the presentations of the conference, and was published in Athens the same year.

I presented the research results to my students within the framework of the optional course "The History of Cartel Law", for which I also developed digital study materials. I give regular presentations in connection to the history of cartel law to my esteemed audience on "Researchers' Night". In connection to the research topic, I am also taking part in the mentoring of a $\mathrm{PhD}$ student as an assistant consultant on the topic of unfair competition.

In the third year of my research, I presented my habilitation lecture on the topic of cartel supervision. "The Introduction of Cartel Supervision in Hungary. The Codification and Practice of the $20^{\text {th }}$ Act of 1931 " was published as the $83^{\text {rd }}$ volume of the series entitled The Library of the Elemér Pólay Foundation in 2020. During the final year of the research, I finalized analysis of the sources, and the results of the research were released in the form of essays and conference presentations. The theoretical and practical examination of the regulations of cartel supervisory agencies allowed us to learn about the development of cartel law in Hungary, which further allowed us to utilise the research results in the $21^{\text {st }}$ century. The aforementioned monograph contains the summarization of the present-day research results, but this does not mean that the research on the history of cartel law is finished. I have plans to further analyse not only formal legal regulations, but also matters of substantive law via the examination of more recent economic history sources and company documents. 